\title{
INTERESPECIFIC COMPETITION BETWEEN PECKIA CHAYSOSTOMA AND ADISCOCHAETA INGENS (DIPTERA: SARCOPHAGIDAE) LARVAE REARED IN LABORATORY
}

\author{
MARISA VIANNA FERRAZ
}

Departamento de Biologia, Instituto Oswaldo Cruz, Av. Brasil, 4365, 21045-900 Rio de Janeiro, RJ, Brasil

Groups of 10 and 20 first instar larvae of Peckia chrysostoma (Wiedemann, 1830) were combined in a proteic source media with groups of the same number of first instar larvae of Adiscochaeta ingens (Walker, 1849), under the environmental conditions of Rio de Janeiro, $R J$, Brasil. P. chrysostoma and A. ingens obtained average competitive potentials of $94.0 \pm 2.0 \%$ and $31.0 \pm 5.0 \%$ respectively.

In the second experiment, larvae of $\mathrm{P}$. chrysostoma were introduced approximately $15 \mathrm{hr}$ after the introduction of $\mathrm{A}$. ingens larvae (whose majority had already passed to the second instar) in the media. The corresponding average competitive potential of P. chrysostoma (82.0 $\pm 2.0 \%)$ was decreased when compared to the first experiment, but still greater than that of A. ingens $(64.5 \pm 9.5 \%)$. The competitive potential of A. ingens, however, increased significatively, demonstrating the influence of its previous colonization in the media for achieving a higher viability.

In both experiments the competitive potential of $\mathrm{P}$. chrysostoma was greater and similar to observations cited in the literature.

Control-groups of each species were observed, individually, for the comparison. The mean value obtained for $\mathrm{P}$. chrysostoma was $94.0 \pm 3.7 \%(0.0 \%$ [experiment 1$]$ and only $12.8 \%$ [experiment 2] greater than the average competitive factor). For A. ingens the average was 86.0 $\pm 7.3 \%(64.0 \%$ [experiment 1$]$ and $25.0 \%$ [experiment 2$]$ greater than the average competitive factor).

Key words: interespecific competition - viability - Peckia chrysostoma - Adiscochaeta ingens - Diptera Sarcophagidae

These studies are a series of studies (Ferraz, 1992a; 1992b, among others), made in laboratory, on the comparative biology of Peckia chrysostoma and Adiscochaeta ingens, two species of caliptrate muscoids. Results are shown herein about interespecific competition between larvae of one autochthonal species, $P$. chrysostoma, and an introduced species, $A$. ingens.

P. chrysostoma, a neotropic and sinantropic species, has a recorded geographic distribution in St. Thomas, Tobago, Jamaica, Mexico, Nicaragua, Panama, Trinidad, Guyana, Brazil

This work was supported by CAPES.

Received 7 August 1992.

Accepted 26 January 1993. and Argentina (Lopes, 1969). In Rio de Janeiro (Brazil) it has a wide distribution and is frequently found in high densities. It constituted the majority among other species of Sarcophagid flies. A. ingens has a cited distribution in Mexico, Panama, Puerto Rico, Colombia, Venezuela, Guyana, Brazil, Paraguay and Argentina (Lopes, 1969). The latter is a species characteristic of the Brazilian "campos cerrados" (CC), where it was collected. While $A$. ingens is found in Rio de Janeiro, it occurs in numbers of little significance.

\section{MATERIALS AND METHODS}

In the $P$. chrysostoma study, descendent strains of native populations were collected from the campus of Instituto Oswaldo Cruz, Rio de Janeiro (IOC-RJ). We made four col- 
lections, at intervals of three months. The colony of $A$. ingens originated from larvae collected at CC Brasília (DF), Brazil. The colonies were kept isolated, being thus prevented to crossing between native populations.

Classical traps described by Ferreira (1975) and Linhares $(1979 ; 1981)$ were used with baits of deteriorated raw fish and bovine liver for field collections.

The colonies established in the Diptera Caliptrata Laboratory of the Department of Biology, $\mathrm{OC}-\mathrm{RJ}$, were maintained in wired cages of $30 \times 30 \times 30 \mathrm{~cm}$ which contained water, brown sugar and the proteic source and/ or larviposition media of raw fish.

Twenty first instar larvae of $P$. chrysostoma were introducted in a proteic source media (raw fish) with 20 first instar larvae of the species collected at $\mathrm{CC}$ ( $A$. ingens). The percentage of emerged adults of each species defined its corresponding competitive potential (CP). Five repetitions were done, allowing thus to calculate a CP average of each species. The proportion of media per larvae which led to an optimum development of the larvae and to a production of well developed adults was, approximately, $2 \mathrm{~g}$ per larvae. In order to observe if the group factor affects the results, we repeated the above procedure using five groups of ten larvae of each species. The first experiment included, thus, the above six groups.

\section{TABLE I}

Viability of Peckia chrysostoma and Adiscochaeta ingens larvae, reared isolately, under laboratory conditions, beginning with 20 larvae of first instar

\begin{tabular}{ccrcc}
\hline \multirow{2}{*}{ Groups } & \multicolumn{2}{c}{$P$ chrysostoma } & \multicolumn{2}{c}{ A. ingens } \\
& No. adults & $\%$ & No. adults & $\%$ \\
\hline 1 & 20 & 100 & 19 & 95 \\
2 & 18 & 90 & 16 & 80 \\
3 & 19 & 95 & 19 & 95 \\
4 & 18 & 90 & 16 & 80 \\
5 & 19 & 95 & 16 & 80 \\
\hline Mean & $94.0 \pm 3.7$ & $86.0 \pm 7.3$ \\
\hline
\end{tabular}

After determining the most adapted species (i.e., the one which presented the highest CP average) we started the second experiment. The second study differs from the first one by selecting larvae of the most adapted species and introducing them in the media, approximately, $15 \mathrm{hr}$ after the introduction of larvae of the other species (whose majority had already passed to the second instar by this time).

In order to compare the $\mathrm{CP}$ with its real viability, for each species, a third experiment was conducted for five control-groups, each of which with 20 first instar larvae of only one species. The larvae of each control-group were introduced in a media with proteic source and the percentage of emerged adults was used to define its viability.

TABLE II

Competitive potentials of Peckia chrysostoma and Adiscochaeta ingens larvae introduced simultaneously and maintained under laboratory conditions

\begin{tabular}{|c|c|c|c|c|c|c|c|c|c|}
\hline \multirow[b]{2}{*}{$\begin{array}{l}\text { No. of } \\
\text { larvae }\end{array}$} & \multirow[b]{2}{*}{ Group } & \multicolumn{4}{|c|}{$P_{*}$ chrysostoma } & \multicolumn{4}{|c|}{ A. ingens } \\
\hline & & $\mathbf{E}$ & $\begin{array}{l}\mathrm{CP} \\
(\%)\end{array}$ & $\begin{array}{c}\text { Mean } \\
(\%)\end{array}$ & $\begin{array}{l}\mathrm{SE} \\
(\%)\end{array}$ & $\mathrm{E}$ & $\begin{array}{l}\mathrm{CP} \\
(\%)\end{array}$ & $\begin{array}{c}\text { Mean } \\
(\%)\end{array}$ & $\underset{(\%)}{\mathrm{SE}}$ \\
\hline 10 & $\begin{array}{l}1 \\
2 \\
3 \\
4 \\
5\end{array}$ & $\begin{array}{r}10 \\
10 \\
9 \\
10 \\
9\end{array}$ & $\begin{array}{r}100 \\
100 \\
90 \\
100 \\
90\end{array}$ & 96.0 & 4.9 & $\begin{array}{l}5 \\
2 \\
4 \\
3 \\
4\end{array}$ & $\begin{array}{l}50 \\
20 \\
40 \\
30 \\
40\end{array}$ & 36.0 & 10.2 \\
\hline 20 & $\begin{array}{l}1 \\
2 \\
3 \\
4 \\
5\end{array}$ & $\begin{array}{l}19 \\
18 \\
18 \\
19 \\
18\end{array}$ & $\begin{array}{l}95 \\
90 \\
90 \\
95 \\
90\end{array}$ & 92.0 & 2.4 & $\begin{array}{l}7 \\
5 \\
3 \\
4 \\
7\end{array}$ & $\begin{array}{l}35 \\
25 \\
15 \\
20 \\
35\end{array}$ & 26.0 & 8.0 \\
\hline Average & & & & 94.0 & 2.0 & & & 31.0 & 5.0 \\
\hline
\end{tabular}

$\mathrm{E}$ : emergence of adults; $\mathrm{CP}$ : competitive potential; $\mathrm{SE}$ : standard deviation 
TABLE III

Competitive potentials of Peckia chrysostoma, introduced in the media approximately $15 \mathrm{hr}$ after Adiscochaeta ingens larvae maintained under laboratory conditions

\begin{tabular}{|c|c|c|c|c|c|c|c|c|c|}
\hline \multirow[b]{2}{*}{$\begin{array}{l}\text { No. of } \\
\text { larvae }\end{array}$} & \multirow[b]{2}{*}{ Group } & \multicolumn{4}{|c|}{ P. chrysostoma } & \multicolumn{4}{|c|}{ A. ingens } \\
\hline & & $E$ & $\begin{array}{l}\text { CP } \\
(\%)\end{array}$ & $\begin{array}{c}\text { Mean } \\
(\%)\end{array}$ & $\underset{(\%)}{\mathrm{SE}}$ & $\mathbf{E}$ & $\begin{array}{l}C P \\
(\%)\end{array}$ & $\begin{array}{c}\text { Mean } \\
(\%)\end{array}$ & $\begin{array}{l}\mathrm{SE} \\
(\%)\end{array}$ \\
\hline 10 & $\begin{array}{l}1 \\
2 \\
3 \\
4 \\
5\end{array}$ & $\begin{array}{r}10 \\
8 \\
7 \\
8 \\
9\end{array}$ & $\begin{array}{r}100 \\
80 \\
70 \\
80 \\
90\end{array}$ & 84.0 & 10.2 & $\begin{array}{l}9 \\
7 \\
6 \\
6 \\
9\end{array}$ & $\begin{array}{l}90 \\
70 \\
60 \\
60 \\
90\end{array}$ & 74.0 & 13.6 \\
\hline 20 & $\begin{array}{l}1 \\
2 \\
3 \\
4 \\
5\end{array}$ & $\begin{array}{l}17 \\
14 \\
17 \\
17 \\
15\end{array}$ & $\begin{array}{l}85 \\
70 \\
85 \\
85 \\
75\end{array}$ & 80.0 & 6.3 & $\begin{array}{r}14 \\
11 \\
7 \\
10 \\
13\end{array}$ & $\begin{array}{l}70 \\
55 \\
35 \\
50 \\
65\end{array}$ & 55.0 & 12.2 \\
\hline Average & & & & 82.0 & & & & 64.5 & \\
\hline
\end{tabular}

E: emergence of adults; $\mathrm{CP}$ : competitive potential; $\mathrm{SE}$ : standard deviation.

\section{TABLE IV}

Chi-square analysis of adult emergence in relation to the number of larvar reared together. Numbers in parentheses indicate the expected values according to the null hypothesis

\begin{tabular}{cccccc}
\hline \multirow{2}{*}{ Species } & \multirow{2}{*}{ Exper. } & Emergence & \multicolumn{2}{c}{ No. of larvae } & \multicolumn{2}{c}{ Statistics } \\
& & & 10 & 20 & $\chi^{2}=0.818$ \\
PC & 1 & Yes & $48(46.7)$ & $92(93.3)$ & $\rho>0.05$ \\
& & No & $2(3.3)$ & $8(6.7)$ & $\rho>0.334$ \\
& 2 & Yes & $42(40.7)$ & $80(81.3)$ & $\chi^{2}=0.05$ \\
AI & No & $8(9.3)$ & $20(18.7)$ & $\rho>0.05$ \\
& 1 & Yes & $18(14.7)$ & $26(29.3)$ & $\chi^{2}=1.575$ \\
& 2 & No & $32(35.3)$ & $74(70.7)$ & $\rho>0.05$ \\
& & Yes & $37(30.7)$ & $55(61.3)$ & $\chi^{2}=3.022$ \\
& & No & $13(19.3)$ & $45(38.7)$ & $\rho>0.05$ \\
\hline
\end{tabular}

$\chi^{2}:$ chi-square; $\rho$ : probability; PC : Peckia chrysostoma; AI $:$ Adiscochaeta ingens, Degree of freedon $=1$.

These experiments were done under the environmental conditions of Rio de Janeiro with a mean temperature of $28.5^{\circ} \mathrm{C}$ (mean minimum $26.5^{\circ} \mathrm{C}$ and mean maximum $30.5^{\circ} \mathrm{C}$ temperatures) and mean relative humidity of $68.5 \%$ (minimum $56.0 \%$ and maximum $82.0 \%$ $\mathrm{RH})$.

\section{RESULTS}

The viabilities of the five control-groups and their averages are shown, for each species, in Table I. Both species demonstrated a high viability, with no significant differences in the emergence between the species when there was no competition.
The results of the first and second experiments are displayed on Table II and III respectively. The analysis of the significance is displayed on Tables IV, V, VI and VII. From these we can see, for all the cases with different numbers of larvae in the two first experiments, that the $\mathrm{CP}$ average of $P$. chrysostoma was significatively higher than that of $A$. ingens. In the second experiment the $\mathrm{CP}$ average of $P$. chrysostoma decreased, although it was still greater when compared to that of $A$. ingens. On the contrary there was a significative increase in the $\mathrm{CP}$ average of $A$. ingens. There was no significative difference between the experiments conducted with 10 or 20 larvae for each of the species. 


\section{TABLE V}

Chi-square analysis of adult emergence in relation to the species. Numbers in parentheses indicate the expected values according to the null hypothesis

\begin{tabular}{ccrcc}
\hline Exper. & Emergence & \multicolumn{1}{c}{ PC } & Species & AI \\
\hline 1 & Yes & $140(92.0)$ & $44(92.0)$ & $\chi^{2}=129.534$ \\
& No & $10(58.0)$ & $106(58.0)$ & $\rho<0.05$ \\
2 & Yes & $122(107.0)$ & $92(107.0)$ & $\chi^{2}=14.672$ \\
& No & $28(43.0)$ & $58(43.0)$ & $\rho<0.05$ \\
3 & Yes & $94(90.0)$ & $86(90.0)$ & $\chi^{2}=3.556$ \\
& No & $6(10.0)$ & $14(10.0)$ & $\rho>0.05$ \\
\hline
\end{tabular}

$\overline{\chi^{2}}$ : chi-square; $\rho$ : probability; PC: Peckia chrysostoma; AI: Adiscochaeta ingens. Degree of freedon $=1$.

\section{TABLE VI}

Chi-square analysis of adult emergence in relation to the competition between Peckia chrysostoma (PC) and Adiscochaeta ingens (AI). Numbers in parentheses indicate the expected values according to the null hypothesis

\begin{tabular}{cccccc}
\hline \multirow{2}{*}{ Species } & \multirow{2}{*}{ Exper. } & Emergence & Yes & Nompetition & Statistics \\
\hline PC & 1 & Yes & $140(140.4)$ & $94(93.6)$ & $\chi^{2}=0.045$ \\
& & No & $10(9.6)$ & $6(6.4)$ & $\rho>0.05$ \\
& 2 & Yes & $122(129.6)$ & $94(86.4)$ & $\chi^{2}=8.192$ \\
& & No & $28(20.4)$ & $6(13.6)$ & $\rho<0.05$ \\
AI & 1 & Yes & $44(78.0)$ & $86(52.0)$ & $\chi^{2}=77.189$ \\
& & No & $106(72.0)$ & $14(48.0)$ & $\rho<0.05$ \\
& 2 & Yes & $92(106.8)$ & $86(71.2)$ & $\chi^{2}=17.802$ \\
& & No & $58(43.2)$ & $14(28.8)$ & $\rho<0.05$ \\
\hline
\end{tabular}

$\chi^{2}:$ chi-square; $\rho:$ probability. Degree of freedom $=1$.

\section{TABLE VII}

Chi-square analysis of adult emergence in relation to the experiments 1 and 2 . Numbers in parentheses indicate the expected values according to the null hypothesis

\begin{tabular}{ccccc}
\hline \multirow{2}{*}{ Species } & Emergence & 1 & Experiments & Statistics \\
& & 1 & 2 & \\
\hline PC & Yes & $140(131.0)$ & $122(131.0)$ & $\chi^{2}=9.762$ \\
& No & $10(19.0)$ & $28(19.0)$ & $\rho<0.05$ \\
AI & Yes & $44(68.0)$ & $92(68.0)$ & $\chi^{2}=30.990$ \\
& No & $106(82.0)$ & $58(82.0)$ & $\rho<0.05$ \\
\hline
\end{tabular}

$\chi^{2}$ : chi-square; $\rho$ : probability; PC: Peckia chrysostoma; AI: Adiscohaeta ingens. Degree of freedom $=1$.

Comparing the CP average of the two experiments (Tables II and III) with the viabilities obtained with the control groups (Table I) we showed that the average viability of the control-groups of $P$. chrysostoma was $0.0 \%$ (experiment 1 ) and only $12.8 \%$ (experiment 2 ) higher than its $\mathrm{CP}$ average. For $A$. ingens the average viability was $64.0 \%$ (experiment 1 ) and $25.0 \%$ (experiment 2) higher than its $\mathrm{CP}$ average. This shows, except in the case of $P$. chrysostoma for the first experiment, the relevant influence of the presence of another species in the same rearing media.

\section{DISCUSSION}

As we have seen above, viability of $P$. chrysostoma was greater than for $A$. ingens. 
This agrees with previous observations from different regions of Brazil, except in the CC. For instance, d'Almeida (1984) observed a high incidence $(26.66 \%)$ of $P$. chrysostoma among the total number of dipterous insects collected in the state of Rio de Janeiro where this species demonstrated preference for environments inhabited by man. In the state of Minas Gerais, it was more frequently collected in forest arcas (Dias et al., 1984). Tavares et al. (1988) observed the prevalence of this species (521 among 1138 collected individuals) in their studies of communities of Sarcophagid flies. $A$. ingens, when mentioned in the literature, is usually cited as an unfrequently collected species in Rio de Janeiro state (d'Almeida, 1984). This was also observed in Minas Gerais state (Dias et al., 1984). In the city of Campinas, state of São Paulo, Linhares (1981) collected only four specimens of $A$. ingens against 283 of $P$. chrysostoma, the later species showing a sinanthropic index of +13.9 (hemi-sinanthropic) and being more attracted by rat carcass and chicken viscerals. Lopes (1973) has done extensive work for 40 years on the distribution and density of the Sarcophagidae. His observations constantly showed greater numbers of $P$. chrysostoma when compared to $A$. ingens. However, in the state of Ceará, Lopes (1974) found low densities for both species: only $0.15 \%$ and $0.1 \%$ of individuals of $P$. chrysostoma and $A$. ingens, respectively, of the total of the species collected by him with banana and brown sugar baits. In the state of Mato Grosso, where the CC are localized, Lopes \& Tibana (1982) also found low densities for both species, but greater numbers of $A$. ingens: $0.23 \%$ and $0.77 \%$ of individuals of $P$. chrysostoma and $A$. ingens, respectively. Comparing the results of the two first experiments we observe a significant reduction of the viability of $P$. chrysostoma and a significant increase of the viability of $A$. ingens when the larvae of the most adapted species ( $P$. chrysostoma) were combined in media only after the larvae of the less adapted species ( $A$. ingens) had passed to the second instar. These results show the relevance of previous colonization by $A$. ingens in the media in order to obtain greater chances of survival when competing with a more adapted species. The agreement between the present work and the literature lead us to conclude that our results are an estimate of what occurs in natural environment.

Comparing the mean $\mathrm{CP}$ of $A$. ingens with the mean viability obtained from the control- groups, we suggest two possible explanations for results: (a) P. chrysostoma larvae could be predatious on $A$. ingens larvae decreasing the number of emerged adults; (b) The production of salivary glands secretion or waste products by $P$. chrysostoma larvae could produce an unfavourable environment for $A$. ingens (process known as antibiose). We believe that the latter would be the most probable possibility as predation by $P$. chrysostoma has not been shown in the literature and because there was enough food for the larvae to consume throughout their immature life cycle. The amount of food required is proportional to the larval size. Both species are relatively large and the amount of food utilized ( $2 \mathrm{~g}$ per larvae) was more than sufficient for optimum larvae development. For small species as Musca domestica, for instance, only 8 to $9 \mathrm{~g}$ of larval media are required to rear approximately 100 flies (Frings, 1948).

In agreement with Amano (1984), Kamal (1958), Shahein (1986) and So \& Dudgeon (1989), the density of larvae rearing influences on the survival, the time of development, the abundance and on the size of an adult insect. Baxter et al. (1973) observed that the size of an adult insect was influenced by the expression of autogeny in Sarcophaga bullata. In the experiments with 10 and 20 larvae, however, the statistical analysis shows that there was no significant influence of the number of reared larvae on the $C P$.

The number of emerged $P$. chrysostoma adults was lower in the first experiment but not significantly different in viability when compared with that of the control-groups. This suggests that the $\mathrm{CP}$ of this species is also changed by the presence of $A$. ingens. A. ingens had a significant reduction in the viability in the two experiments when compared with the control-groups. Hutton \& Wasti (1980), in their work about Calliphoridae, observed an extreme case: not only a reduction in the viability of Phaenicia regina, species less competitive, but its total elimination by Phaenicia sericata, a species more competitive. Contrary to their observation, the development of the less competitive species in the present work (A. ingens) was not completely annihilated, in any level of tested density, by the winner species, obtaining still an average viability of 31.0 $\pm 5.0 \%$ (experiment 1 ) and $64.5 \pm 9.5 \%$ (experiment 2). 


\section{ACKNOWLEDGEMENTS}

To Dr Hugo de Souza Lopes, in memorian, for his inestimable supervision during this study. To Dr Rubens Pinto de Mello, for his valuable observations and comments, to Dr. Otávio Pieri for the statistical analysis and to Dr Aglae Cristina Navarro de Magalhães, for the English review.

\section{REFERENCES}

d'ALMEIDA, J. M., 1984. Sinantropia de Sarcophagidae (Diptera) na região metropolitana do Estado do Rio de Janeiro. Arq. Univ. Fed. Rur. Rio de Janeiro, 7 : 101-110.

AMANO, K., 1984. Studies on the intraspecific competition in dung-breeding flies. II. Some biological phenomena induced by overcrowding in immature stages of Musca hervei Villeneuve (Diptera: Muscidae). Jap. J. Sanit. Zool, 35: 333-341.

BAXTER, J. A.; MJENI, A. M. \& MORRISON, P. E., 1973. Expression of autogeny in relation to larval population density of Sarcophaga bullata Parker (Diptera: Sarcophagidae). Can. J. Zool, 5I: 1189. 1193.

DIAS, E. S.; NEVES, D. P. \& LOPES, H. S., 1984. Estudos sobre a fauna de Sarcophagidae (Diptera) de Belo Horizonte - Minas Gerais. I - Levantamento taxonômico e sinantrópico. Mem. Inst. Oswaldo Cruz, 79: 83-91.

FERRAZ, M. V., 1992a. Comparison of the reproductive behavior between isolated Peckia chrysostoma (Wiedemann, 1830) and Adiscochaeta ingens (Walker, 1849) (Diptera: Sarcophagidae) females reared in laboratory. Mem. Inst. Oswaldo Cruz, 87 : 131-139.

FERRAZ, M. V., 1992b. Estudos comparados do desenvolvimento biológico e do comportamento de Peckia chrysostoma (Wiedemann, 1830) e Adiscochaeta ingens (Walker, 1849) (Diptera: Sarcophagidae) em condições de laboratório. MSc Thesis Inst. Oswaldo Cruz, $138 \mathrm{p}$.

FERREIRA, M. J. M., 1975. Sinantropia de dipteros muscoides de Curitiba (Calliphoridae e Sarcophagidae). MSc Thesis U. F. Paraná, 106 p.
FRINGS, H., 1948. Rearing houseflies and blowflies on dog biscuit. Science, 107: 629-630.

HUTTON, G. F. \& WASTI, S. S., 1980. Competitive interactions between larvae of the green bottle fly, Phaenicia sericata (meig.) and the black blow fly, Phormia regina (Meig.). Comp. Physiol. Ecol., 5: I-4.

KAMAL, A. S., 1958. Comparative study of thirteen species of sarcosaprophagous Calliphoridae and Sarcophagidae (Diptera) I. Bionomics. Ann. Ent. Soc. Am., 51: 261-271.

LINHARES, A. X., 1979. Sinantropia de dipteros muscoides de Campinas. MSc Thesis UNICAMP, $129 \mathrm{p}$.

LINHARES, A. X., 1981. Synanthropy of Calliphoridae and Sarcophagidae (Diptera) in the city of Campinas, São Paulo, Brazil. Rev. brasil. Ent., 25: 189-215.

LOPES, H. S., 1969. Family Sarcophagid. In $A$ catalogue of the Diptera of the Americas South of the United States. Dep. Zool. Sec. Agric. São Paulo, 103: 1 -88.

LOPES, H. S., 1973. Collecting and rearing sarcophagid flies (Diptera) in Brazil during forty years. An. Acad. brasil. Cienc., 45: 279-291.

LOPES, H. S., 1974. Sarcophagid flies Diptera from Pacatuba, state of Ceará, Brazil. Rev. brasil. Biol., 34: 271-294.

LOPES, H. S. \& TIBANA, R., 1982. Sarcophagid flies (Diptera) from Sinop, state of Mato Grosso, Brazil. Mem. Inst. Oswaldo Cruz, 77: 285-298.

SHAHEIN, A., 1986. Effect of intraspecific competition between larvae of Calliphora erythrocephala (Meig.) (Calliphoridae, Diptera). Z. Angew. Zool., 73: 245-248.

SO, P. M. \& DUDGEON, D., 1989. Life-history responses of larviparous Boettcherisca formosensis (Diptera: Sarcophagidae) to larval competition for food, including comparisons with oviparous Hemipyrellia ligurriens (Calliphoridae). Ecol. Entomol., 14: 349-356.

TAVARES, D. E. S.; PORTHUN, J. R; FERNANDES, E. A. \& OLIVEIRA, S. P., 1988. Estudo sobre comunidades de sarcofagideos sinantrópicos (Diptera, Sarcophagidae) no Instituto Oswaldo Cruz, Manguinhos, RJ. Resumos XV Congr. brasil. Zool., Curitiba-PR, p. 233. 